The Editors of the Proceedings of The Nutrition Society accept no responsibility for the abstracts of papers read at the Society's meetings for original communications. These are published as received from the authors.

\title{
ABSTRACTS OF COMMUNICATIONS
}

The One Hundred and Fifty-fifth Meeting of The Nutrition Society was held at Queen's College, Dundee, on Friday, 8 February 1963, at I.30 p.m., when the following papers were read:

Daily variation in human body-weight. By T. Khosla and F. E. Hytten, Research Group in Biometric Medicine and Obstetric Medicine Research Unit (Medical Research Council), University of Aberdeen

Change in body-weight is frequently used in nutritional experiments but little is known about the day-to-day variability of this measurement (Elkinton \& Danowski, I955; Taggart, I962).

This preliminary communication deals with variations in body-weight in healthy subjects. About forty consecutive daily weights were recorded for two families living at home and for a woman in late pregnancy living in hospital. Steel yard balances calibrated to I oz were used and weighing took place between 7 and 9 a.m., before breakfast and after emptying the bladder. The remaining adults were female office workers, one of whom was pregnant. They were weighed on working days for a period of 5 weeks at 9 a.m., care being taken to standardize the weight of clothing. In addition two healthy babies in hospital were weighed for 14 consecutive days to the nearest $\frac{1}{4} \mathrm{Oz}$.

Unless the weight was stationary over the period the daily variation was measured as deviations from the trend. Linear or simple quadratic equations were adequate to describe the trends. The table summarizes the results, which indicate that over the whole range of subjects the standard deviation of daily fluctuations of body-weight about a trend is about $0.5 \%$ of the mean weight.

Daily variation in body-weight

\begin{tabular}{|c|c|c|c|c|c|}
\hline Subjects & Sex & $\begin{array}{c}\text { Age } \\
\text { (years) }\end{array}$ & $\begin{array}{c}\text { Mean } \\
\text { body-weight } \\
\text { (lb) }\end{array}$ & $\begin{array}{l}\text { SD about } \\
\text { trend } \\
\text { (lb) }\end{array}$ & $\begin{array}{c}\text { Coefficient } \\
\text { of variation } \\
\frac{\mathrm{sD}}{\mathrm{M}} \times 100\end{array}$ \\
\hline Family I: F.E.H. & M & 40 & I77 & 0.92 & 0.52 \\
\hline C.A.H. & F & 40 & I36 & 0.76 & 0.56 \\
\hline P.A.H. & $\mathrm{F}$ & 13 & I 18 & 0.70 & 0.59 \\
\hline M.K.H. & $\mathbf{F}$ & I I & 96 & 0.54 & 0.56 \\
\hline P.L.H. & M & 8 & 64 & 0.42 & 0.65 \\
\hline Family $2:$ T.K. & M & 40 & r77 & 0.74 & 0.42 \\
\hline S.K. & $\mathrm{F}$ & 35 & 155 & 0.84 & 0.54 \\
\hline N.K. & M & 12 & 99 & 0.46 & 0.47 \\
\hline Pregnant woman: A. & $F$ & 26 & 163 & 0.78 & 0.48 \\
\hline H. & F & 24 & 147 & 0.62 & 0.42 \\
\hline Non-pregnant woman: G.A.L. & $\mathrm{F}$ & 19 & I 39 & 0.66 & 0.47 \\
\hline M.A. & $\mathrm{F}$ & 26 & II 7 & 0.47 & 0.40 \\
\hline M.G. & F & 16 & 109 & 0.50 & 0.46 \\
\hline M. & $F$ & 18 & 109 & 0.51 & 0.47 \\
\hline $\begin{array}{r}\text { Baby: L.D. } \\
\text { M.C. }\end{array}$ & $\begin{array}{l}\mathrm{F} \\
\mathrm{F}\end{array}$ & $\begin{array}{l}\text { I } \\
4 \text { days }\end{array}$ & $\begin{array}{r}8.7 \\
6.9\end{array}$ & $\begin{array}{l}0.110 \\
0.043\end{array}$ & $\begin{array}{l}0.59 \\
0.62\end{array}$ \\
\hline
\end{tabular}


There appears to be no relationship between the coefficient of variation and age or sex. Menstruation was not associated with any consistent weight change, but we have the impression that a more active life with variable activities leads to a greater degree of weight fluctuation.

\section{REFERENCES}

Elkinton, J. R. \& Danowski, T. S. (I955). The Body Fluids. Baltimore: The Williams and Wilkins Co. Taggart, N. (1962). Brit. F. Nutr. 16, 223.

The specific dynamic effect of protein. By A. K. Martin and K. L. Blaxter, Hannah Dairy Research Institute, Kirkhill, Ayr

The commonly accepted values for the metabolizable energy of protein are those of Rubner ( 1885 ) of $4 . \mathrm{I} \mathrm{kcal} / \mathrm{g}$ and of Atwater ( 1900 ) of $4.0 \mathrm{kcal} / \mathrm{g}$. Values given for the specific dynamic effect (SDE) of proteins are frequently reported (Lusk, $193 \mathrm{I}$ ) as varying between 30 and $40 \%$ of their metabolizable energy.

Seven experiments were made with sheep with permanent fistulas of the abomasum. Each was kept in a respiration chamber and starved for 14 days. Metabolism of energy and nitrogen was measured on each day. During the first 5 days, I 1. of saline was infused into the abomasum daily. From the 6 th to the Ioth day of fast in six of the experiments, I 1 . of a $6 \%(\mathrm{w} / \mathrm{v})$ solution of casein was infused and in one experiment a $6 \%$ solution of egg-white proteins. Saline was again infused from the I Ith to the I $4^{\text {th }}$ day of fast. Fermentation of the protein in the rumen was avoided by the abomasal method of administration.

The results obtained are summarized in Table $\mathrm{I}$ where they are compared with Rubner's results with meat. Both casein and egg-white proteins had a higher heat of combustion than Rubner's meat protein. No loss of energy in faeces occurred with the proteins given to sheep, but Rubner assumed a $3 \%$ loss in faeces. Rubner calculated that more energy was lost in urine on oxidation of meat protein than was found with casein or egg-white protein. The metabolizable energy of casein and eggwhite, expressed on the basis of $16 \% \mathrm{~N}$ was therefore about $20 \%$ higher than the accepted values of $4^{\cdot 0-4} \cdot \mathrm{I} \mathrm{kcal} / \mathrm{g}$ based on Rubner's work. The increment of heat for casein of $18 \cdot 3+1.5 \%$ agrees with calculations based on the amino acid composition of casein and the free energy yielded on oxidation in the body of the amino acids it contains (Krebs, I960; Martin \& Blaxter, I963). The SDE for egg-white is in agreement with the SDE for casein and the values for both proteins are about half

Table I. Metabolism of proteins by sheep and by Rubner's dog

Heat of combustion (ash-free) (kcal/g)

$\mathrm{N}(\%)$

Faecal loss (kcal/g)

Urine loss of energy (kcal/g)

Metabolizable energy $(\mathrm{kcal} / \mathrm{g})$

Metabolizable energy ( $\mathrm{kcal} / \mathrm{g}$ for $16.0 \% \mathrm{~N}$ )

Specific dynamic effect (kcal/100 kcal metabolizable energy)

Net energy value of protein for maintenance $(\mathrm{kcal} / \mathrm{g})$

Casein
$5.936 \pm 0.036$
$15.54 \pm 0.12$
$\mathrm{Nil}$
$1.045 \pm 0.079$
$4.891 \pm 0.096$
$5.038 \pm 0.128$
$18.3 \pm 1.5$
$4.116 \pm 0.129$

\section{Egg-white} $5 \cdot 408$ $14 \cdot 21$ 
those usually accepted. Casein and egg-white proteins thus have values as a net energy source for maintenance which exceed those normally accepted for protein by more than $50 \%$. It is thought that this is a general finding not peculiar to the sheep or to the two proteins used.

\section{REFERENCES}

Atwater, W. O. (1900). Rep. Storrs agric. Exp. Sta., I899, p. 69.

Krebs, H. (1960). Arzneimittel-Forschung, 10, 369 .

Lusk, G. (193I). The Elements of the Science of Nutrition, 4 th ed., p. 282. London and Philadelphia: W. B. Saunders Co.

Martin, A. K. \& Blaxter, K. L. (1963). EAAP. Proceedings of the Second Symposium on Energy Metabolism, Wageningen $I 961$, p. 200.

Rubner, M. (1885). Z. Biol. 21, 337.

Rubner, M. (1902). Die Gesetze des Energieverbrauchs bei der Ernährung. Leipzig u. Wien: F. Deutiche.

Effect of a carotene-free diet on the metabolic rate of the goat. By $\mathrm{E}$. C. Owen, R. A. Darroch and R. Proudfoot, Hannah Dairy Research Institute, Kirkhill, Ayr

Five milking goats were stall-fed for several weeks and were then given, in alternate periods, diets containing and not containing greenstuff (dried-grass meal). On changing to greenstuff the heart rate decreased and on changing back the heart rate
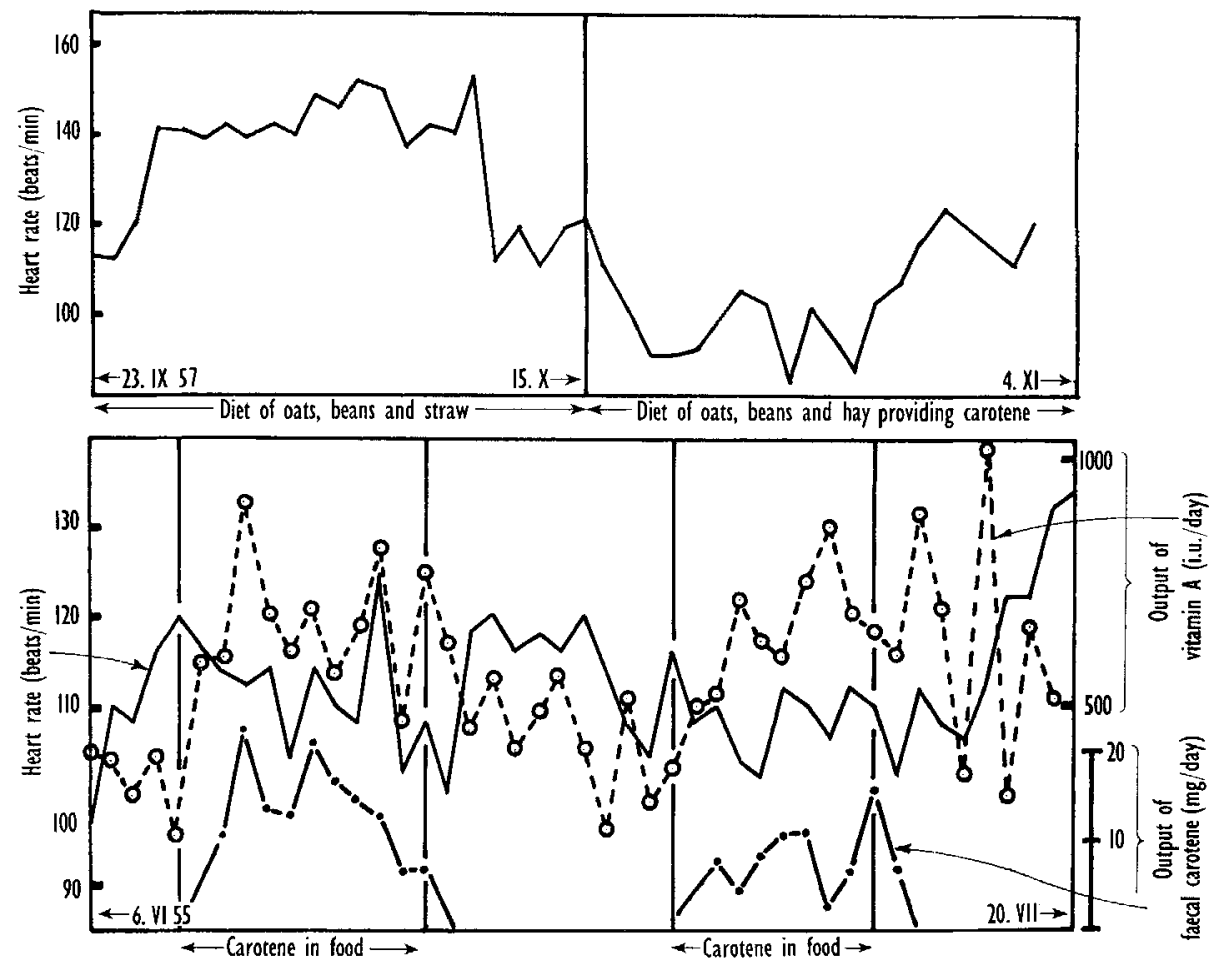

Fig. I. Upper graph shows the change of heart rate of a dry female goat when her food is changed from oats, beans and straw to oats, beans and hay. The lower graph shows the effect of alternating a diet of oats, beans and dried-grass meal with one of oats, beans and straw meal, the former providing initially about $40 \mathrm{mg}$ carotene/day. The heart rate is the conifinuous line. $0--0_{--0}$, vitamin A output in milk; 
increased (see Fig. I). As expected (Fig. I) milk vitamin A increased when the grass was fed and decreased when it was replaced by ground straw. A similar effect on the heart was noted using four other non-lactating goats. However in a later experiment, when fresh-cut grass was fed instead of dried grass to milking goats which had not been deprived of greenstuff beforehand, the effect on the heart was not observed, probably because a partial deficiency of vitamin $\mathrm{A}$ is required to make it evident. One of the five lactating goats had a lower vitamin $A$ in its milk than all the others and it died at the end of period 4 of the experiment (see Fig. I). Its liver contained only 260 i.u. vitamin $\mathrm{A} / \mathrm{g}$ and only 2 i.u. of vitamin A were found per $\mathrm{g}$ in its kidney. These concentrations are lower, and that in the kidney much lower, than those hitherto reported in hyperthyroid goats from this laboratory (Chanda \& Owen, 1952). The known antithyroid action of vitamin $A$ and carotene in a number of species (see books and reviews of Lindquist, I938; Brody, I945; Moore, I957; Goodwin, 1952; Owen, I94I, I947, I95 I, 1954) and the anti-metabolic effect of vitamin A (Leutskii, i96 I) make it reasonable to attribute the effect of carotene deprivation on the heart rate of the goat to the damping of the thyroid by dietary carotene. The interaction of the thyroid and vitamin A is complex (Chanda \& Owen, I952; Owen, I962; Chanda, Clapham \& Owen, I955; Paul, Chanda \& Chakraborty, I962) and may be evident only when the intake of carotene is either too great or too small (Frape, Speer, Hayes \& Catron, I959).

\section{REFERENCES}

Brody, S. (1945). Bioenergetics and Growth. New York: Reinhold Publishing Corp.

Chanda, R., Clapham, H. M. \& Owen, E. C. (1955). Biochem. \%. 6o, 39 I.

Chanda R. \& Owen, E. C. (1952). Biochem. F. 51, 404.

Frape, D. L., Speer, V. C., Hayes, V. W. \& Catron, D. V. (r959). F. Nutr. 68, 333.

Goodwin, T. W. (1952). The Comparative Biochemistry of the Carotenoids. London: Chapman \& Hall.

Leutskii, K. M. (r96r). Proc. int. Congr. Biochem. v. Moscow. Vol. Io, p. 235.

Lindquist, T. (1938). Studien über das Vitamin A beim Menschen. Uppsala: Appelberg.

Moore, T. (1957). Vitamin A. London: Elsevier Publishing Co.

Owen, E. C. (1941). \%. Dairy Res. 12, 213.

Owen, E. C. (1947). F. Dairy Res. I5, 142.

Owen, E. C. (1951). F. Dairy Res, 18, I 13 .

Owen, E. C. (1954). F. Dairy Res. 21, 408.

Owen, E. C. (1963). World Rev. Nutr. Diet. (In the Press.)

Paul, A. K., Chanda, R. \& Chakraborty, B. C. (1962). Ann. Biochem. 22, 16 I.

\section{Experimental production of phosphorus-deficient rickets in young lambs.}

By R. G. Hemingway, Department of Animal Husbandry and Veterinary Preventive Medicine, University of Glasgow

Eight-week old lambs were transferred to a low-phosphorus diet composed of $38 \%$ sugar-beet pulp, 15\% kibbled locust beans, 10\% flaked maize, 5\% maize-gluten meal, $10 \%$ blood meal, $20 \%$ glucose monohydrate, $\mathrm{I} \% \mathrm{NaCl}$ and $\mathrm{I} \% \mathrm{CaCO}_{3}$ together with adequate vitamins $A$ and $D$. Depending on variations in composition of separate purchases of constituents, this basal diet contained $0.08-0.10 \%$ phosphorus, $0.55-0.65 \%$ calcium and about $14.5 \%$ protein. Some oat straw $(0.07 \% \mathrm{P})$ was also available. Four groups of lambs received this basal diet alone or supplemented with $0 . \mathrm{I}, 0.2$ or $0.5 \% \mathrm{P}$ added as dicalcium phosphate. 
Signs of rickets (visual and X-ray) appeared after about 7 weeks and thereafter became progressively worse for those lambs on both the basal diet and that supplemented with $0.1 \% \mathrm{P}$. Growth was negligible in the control group after this time but some small increase continued with the $0^{\circ} \mathrm{I} \% \mathrm{P}$ supplemented lambs. Fleece quality was also very poor. The health, growth and vigour of the lambs receiving an additional 0.2 or $0.5 \%$ P were normal. Food-conversion ratios were also much superior for these two groups.

At slaughter after 18 weeks on the experimental diet, bone density as measured by $\mathrm{X}$-ray was severely reduced in the control and $0.1 \% \mathrm{P}$ supplemented groups. There were large reductions in bone ash compared with the 0.2 and $0.5 \% \mathrm{P}$ supplemented groups.

Blood $\mathrm{P}$ levels remained normal at $7-10 \mathrm{mg} \mathrm{P} / 100 \mathrm{ml}$ for the two groups of normal lambs but fell to 2.0 and $2.9 \mathrm{mg} \mathrm{P} / 100 \mathrm{ml}$ for the control and $0.1 \% \mathrm{P}$ supplemented groups respectively after 8 weeks. Subsequently, the mean level in the group receiving the additional $0 . \mathrm{I} \% \mathrm{P}$ rose to about $4.0 \mathrm{mg} / 100 \mathrm{ml}$.

Table $1 . \quad$ Mean live weight $(l b)$ and blood phosphorus concentration ( $\mathrm{mg} P / 100 \mathrm{ml}$ ) of young lambs fed on a low-phosphorus diet $(0.08-0.10 \% P)$ and supplemented with dicalcium phosphate

\begin{tabular}{|c|c|c|c|c|c|c|c|c|c|}
\hline \multirow{2}{*}{\multicolumn{2}{|c|}{$\begin{array}{l}\text { Supplement }(\% \mathrm{P}) \\
\text { No. of lambs }\end{array}$}} & 。 & 0.1 & 0.2 & 0.5 & o & 0.1 & 0.2 & 0.5 \\
\hline & & 8 & 8 & 4 & 4 & 8 & 8 & 4 & 4 \\
\hline \multirow[t]{8}{*}{ Weeks } & 0 & I 5.6 & I 5.4 & $25 \cdot 8$ & 25.0 & $6 \cdot 2$ & $6 \cdot 1$ & $7 \cdot 6$ & $7 \cdot 2$ \\
\hline & 3 & 22.0 & $2 I \cdot I$ & 40.5 & $3^{8} \cdot 3$ & $5 \cdot 4$ & $5 \cdot 4$ & $7 \cdot 9$ & $7 \cdot 6$ \\
\hline & 6 & $24 \cdot 6$ & 24.8 & $48 \cdot 5$ & 44.8 & 3.7 & 5.6 & 7.9 & 9.9 \\
\hline & 8 & 25.4 & $26 \cdot 3$ & $52 \cdot 8$ & $52 \cdot 2$ & 2.0 & $2 \cdot 9$ & $6 \cdot 3$ & $9 \cdot I$ \\
\hline & I I & $24 \cdot 6$ & 27.0 & $58 \cdot 3$ & $57 \cdot 8$ & $2 \cdot 8$ & $3 \cdot 3$ & $9 \cdot 3$ & 10.2 \\
\hline & $I_{4}$ & $26 \cdot I$ & 30.9 & 65.0 & $62 \cdot 5$ & $2 \cdot 3$ & $3 \cdot 4$ & 8.8 & $9 \cdot 3$ \\
\hline & 16 & $26 \cdot 5$ & $32 \cdot 3$ & 68.8 & 65.5 & 2.5 & $4 \cdot 1$ & 8.0 & 9.0 \\
\hline & I 8 & $28 \cdot 8$ & $33 \cdot 7$ & $73 \cdot 8$ & $69 \cdot 3$ & $1 \cdot 7$ & 3.8 & $8 \cdot I$ & IO.I \\
\hline \multicolumn{6}{|c|}{$\begin{array}{l}\text { Food conversion (lb/lb live-weight gain) } \\
\% \text { ash in fat-free rib bone }\end{array}$} & $\begin{array}{r}9 \cdot 6 \\
41 \cdot 6\end{array}$ & $\begin{array}{r}7 \cdot 5 \\
53 \cdot 1\end{array}$ & $\begin{array}{r}5 \cdot 5 \\
58 \cdot 6\end{array}$ & $\begin{array}{r}5.5 \\
60.8\end{array}$ \\
\hline
\end{tabular}

This work forms part of a larger project supported by a generous research grant by Minsal Ltd.

Further observations on copper deficiency in rats fed upon meat. By T. Moore, Dunn Nutritional Laboratory, University of Cambridge and Medical Research Council

The production of copper deficiency in piebald rats by a diet of raw meat, supplemented by fat-soluble vitamins, has already been described (Moore, 1962a,b). The abnormalities observed were hypochromotrichia, dental depigmentation and anaemia. These abnormalities could be prevented by the addition to the meat of Io $\mu \mathrm{g} \mathrm{Cu} / \mathrm{g}$ as sulphate. Ilan \& Guggenheim (I96I) have reported that $\mathrm{Cu}$ also prevents anaemia in mice fed upon meat.

In eight separate experiments the addition of $10 \mu \mathrm{g} \mathrm{Cu} / \mathrm{g}$ to raw minced beef steak was found invariably to prevent all signs of copper deficiency in a total of 103 piebald 
rats. The same supplement prevented dental depigmentation and anaemia in albino rats fed upon raw beef. Cu added at $\mathrm{I} \mu \mathrm{g} / \mathrm{g}$ to raw beef only partially prevented signs of $\mathrm{Cu}$ deficiency in piebald rats. Cobalt, Io $\mu \mathrm{g} / \mathrm{g}$, was quite ineffective against the abnormalities, and will be investigated as an antagonist to $\mathrm{Cu}$.

Cooking of the meat, by stewing with half its own volume of tap or distilled water, usually prevented or ameliorated the signs of $\mathrm{Cu}$ deficiency, even in the absence of supplements of $\mathrm{Cu}$. Commercially cooked meats, however, in the form of corned beef or chopped ham, produced severe $\mathrm{Cu}$ deficiency, and promoted much less rapid growth than a diet of unsupplemented raw beef.

The steak used in these experiments contained $16.9 \%$ of its wet weight as fat, which supplied about $68 \%$ of the rats' calorie intake. In seventeen rats fed upon meat with $\mathrm{Cu}$ supplements the livers averaged $4.7 \%$ of the body-weight, and contained $7.5 \%$ of fat (total lipids). In frozen sections, stained with Sudan 4 and haematoxylin, small particles of fat were seen in the cytoplasm of many of the liver cells. In fifteen rats fed upon meat, without $\mathrm{Cu}$ supplements, the livers averaged $6 \cdot 2 \%$ of the bodyweight, and contained only $5.2 \%$ of fat. Fat particles in the liver cells were absent, or very scanty. The differences between the livers of the rats with and without $\mathrm{Cu}$ did not appear to be due to inanition in the unsupplemented rats, since their stomachs at autopsy were of ten greatly distended with undigested meat. $\mathrm{Cu}$ seems to play some role in the metabolism of fat by the liver.

\section{REFERENCES}

Ilan, J. \& Guggenheim, K. (1961). Bull. Res. Coun. Israel, 9E, I7x.

Moore, T. (1962a). Brit. med.F. i, 689.

Moore, T. (1962b). Proc. Nutr. Soc. 21, xxxviii.

\section{Vitamin $A$ and carotenoids in the blood of British men and women during} 1962. By I. M. Sharman, Dunn Nutritional Laboratory, University of Cambridge and Medical Research Council

Levels of vitamin $\mathrm{A}$ and carotenoids in human blood have been investigated by numerous workers, in various parts of the world, during the past 25 years. Leitner, Moore \& Sharman (I960), in perhaps the most extensive investigation in this field, examined blood collected from over rooo subjects during the decade I $948-57$. The subjects came to Dr Leitner as private patients, and were examined either for purposes of employment abroad or life insurance, or as a preliminary for the treatment of minor ailments. Usually they could be described as middle class, but a few manual workers were included. For the whole decade vitamin A averaged I74 i.u./ $100 \mathrm{ml}$ serum for men and $142 \mathrm{i}$.u. in women. For carotenoids the corresponding values were $\mathrm{I} 2 \mathrm{I}$ and $\mathrm{I} 3 \mathrm{I} \mu \mathrm{g} / \mathrm{I} 00 \mathrm{ml}$ respectively. The higher male level of vitamin $\mathrm{A}$ had already been clearly recognized, but evidence of the higher female level of carotenoids had been less convincing.

In recent years only a small minority in our population has been examined, and treated, under arrangements outside the National Health Service. Criticism was possible, therefore, and was indeed brought forward, that the findings of Leitner 
et al. (1960) referred to a privileged class, and did not represent the general population of this country. As a convenient source of further specimens of blood, to which this criticism would not apply, the Blood Transfusion Service was approached. With the kind co-operation of Dr C. B. V. Walker of the East Anglian Regional Centre, specimens were collected from twenty-three men, of mean age 43 and from twentythree women, mean age 40, living in East Anglia. Vitamin A was determined by the $\mathrm{SbCl}_{3}$ reaction and total carotenoids by their yellow colour.

Wide variations were again found in both sexes. For vitamin A average levels of ${ }_{5} 59$ i.u./ $100 \mathrm{ml}$ for men and $\mathrm{I} 2 \mathrm{I}$ i.u. for women were found. The corresponding values for carotenoids were 120 and $\mathrm{I} 3 \mathrm{I} \mu \mathrm{g} / \mathrm{I} 00 \mathrm{ml}$ respectively. For vitamin A these values were only slightly lower than those reported previously for the private patients of Dr Leitner; for carotenoids they were virtually identical. The differences between the sexes, for both vitamin $A$ and carotenoids, were as expected. The levels now found for vitamin A were somewhat higher, and for carotenoids much higher, than values observed in a mental hospital during $195^{\mathrm{I}-2}$, by Leitner et al. (1952). Thus in the hospital the averages, for both sexes combined were i 8 i.u. of vitamin $\mathrm{A}$, and only $53 \mu \mathrm{g}$ of carotenoids per $100 \mathrm{ml}$.

\section{REFERENCES}

Leitner, Z. A., Moore, T \& Sharman, I. M. (r952) Brit. F. Nutr. 6, x. Leitner, Z. A., Moore, T. \& Sharman, I. M. (1960). Brit. Y. Nutr. 14, 57.

Iron loss during menstruation. By G. A. Cheyne and F. E. HytTEN, Obstetric Medicine Research Unit (Medical Research Council), Maternity Hospital, Aberdeen

The average normal woman is said to lose about $12 \mathrm{mg}$ of iron at each menstrual period, but the reported overall range of values has been wide, from 2 to $79 \mathrm{mg}$ (Barer \& Fowler, I936; Millis, I95I ; Baldwin, Whalley \& Pritchard, I96I) suggesting that some abnormally heavy bleeders had been included.

In this investigation, iron loss was measured in women with normal and with abnormally heavy bleeding. Fifteen young nulliparous pupil midwives at Aberdeen Maternity Hospital collected pads and tampons during two to four successive periods. The pads were placed immediately after use in a Polythene bag and in the laboratory were washed and repeatedly rinsed in distilled water by kneading the pads inside the bag. The wash, which had been found to contain all the iron in recovery experiments, was made up to a known volume and iron in an aliquot measured by the method of Ramsay (1957).

The iron losses, for the forty-four periods studied ranged from $\mathrm{I} \cdot 9$ to $26.4 \mathrm{mg}$ (mean $11 \cdot 3 \mathrm{mg}$ ). Generally, the losses were consistent for an individual woman and differences between successive periods were small compared to differences between subjects; more than half the differences between successive periods were less than I. $5 \mathrm{mg}$ and three-quarters were below $3 \mathrm{mg}$. Averaged over the cycle, the mean iron loss is less than $0.5 \mathrm{mg}$ daily; the heaviest loss in the series was less than $\mathrm{r} \cdot 0 \mathrm{mg}$ daily. The average loss of I $\cdot 3 \mathrm{mg}$ of iron represents about $25 \mathrm{ml}$ of whole blood. 
It should be emphasized that we, like most investigators, have studied a convenient group of women who were all nulliparous. They are not necessarily representative of menstruating women generally and we intend to extend our investigations to cover parous women.

In a preliminary investigation of menorrhagia, iron losses were measured during single menstrual periods in four women attending a gynaecological clinic with a complaint of excessive bleeding. The losses were $6.5,27,35$ and $53 \mathrm{mg}$. Thus two women were within the range of our normal series and it is clear that a history of menstrual bleeding from a woman who has no standards of comparison can be misleading. Even in the normal series, there were women losing under $3 \mathrm{mg}$ of iron per period who considered their loss to be 'average' and women in the top half of the range who considered their losses to be 'lighter than average'.

\section{REFERENCES}

Baldwin, R. M., Whalley, P. J. \& Pritchard, J. A. (1961). Amer. F. Obstet. Gynec, 81, 739.

Barer, A. P. \& Fowler, W. M. (1936). Amer. F. Obstet. Gynec. 3I, 979.

Millis, J. (1951). Med. Y. Aust. ii, 874.

Ramsay, W. N. M. (1957). Clin. chim. acta, 2, 214.

The loss of methane and carbon dioxide by belching in sheep. By J. P. Joyce and K. L. Blaxter, Hannah Dairy Research Institute, Kirkhill, Ayr

Klein (1915) showed that the methane excreted from the lungs of cattle was only $30 \%$ of that measured when the animal was confined in a respiration chamber, the difference being due to loss of gas by belching. Similar experiments to Klein's were made with four tracheostomized sheep. $\mathrm{CO}_{2}$ production, $\mathrm{O}_{2}$ consumption and $\mathrm{CH}_{4}$ production were measured firstly on I4I occasions each over I h or $3 \mathrm{~h}$ intervals when the sheep was confined in a respiration chamber and, secondly, on 200 occasions, each over 30 min intervals, using a Douglas Bag technique. The latter technique measured the pulmonary gas exchange alone and these determinations were made at the same times of day as the respiration chamber experiments.

The mean oxygen consumption determined in the respiration chamber was the same as that determined by the Douglas Bag technique irrespective of the amount of food given to the sheep. Methane loss from the lungs was, however, only $17 \%$ of that measured in the chamber and this percentage did not alter despite a fourfold change in the amount of food given each day, from $450 \mathrm{~g}$ to $\mathrm{I} 800 \mathrm{~g}$ of a mixture of dried grass and oats. Little discrepancy between $\mathrm{CO}_{2}$ production measured in the chamber and the measured loss from the lungs was noted when small amounts of food were given. With increased amounts of food, however, the measured production of $\mathrm{CO}_{2}$ in the chamber grossly exceeded that lost from the lungs. The difference between the amounts of $\mathrm{CO}_{2}$ and the $\mathrm{CH}_{4}$ produced in the respiration chamber and that excreted by the lungs was presumed to be belched. The results show that the volume of $\mathrm{CH}_{4}$ plus $\mathrm{CO}_{2}$ presumed to have been belched was 0.81 ./ h when the amount of food given was low and only $\mathrm{I} 1 . \mathrm{CH}_{4}$ was produced each $\mathrm{h}$. When the amount of food given was large and $\mathrm{CH}_{4}$ production was $2.5 \mathrm{l}$./ h an average of 2.41 . 
of a mixture of $\mathrm{CH}_{4}$ and $\mathrm{CO}_{2}$ were belched each hour. The largest amount presumed belched in any experiment was $3.691 . / \mathrm{h}$. With low amounts of food the ratio by volume of $\mathrm{CH}_{4}$ to $\mathrm{CO}_{2}$ in the belch was over $3: \mathrm{I}$, with high amounts of food it was less than $0.7:$ I. Analyses of rumen gas (Brody, I945) show that the ratio by volume of $\mathrm{CH}_{4}$ to $\mathrm{CO}_{2}$ decreases with increased amount of food.

\section{REFERENCES}

Brody, S. (1945). Bioenergetics and Growth. New York: Reinhold Publishing Corp. Klein, W. (1915). Biochem. Z. 72, 169.

The One Hundred and Fifty-eighth Meeting of The Nutrition Society was held at the Royal Society of Medicine, I Wimpole Street, London, W. 1, on Friday, 24 May 1963, when the following papers were read:

\section{The limiting amino acids of groundnut flour and meal as the sole protein} source for the rat. By Alison E. Black and W. F. J. Cuthbertson, Glaxo Research Ltd, Greenford, Middlesex

Comparisons between amino acid analyses of groundnut protein (Harvey, 1956) and the requirements of the rat (Rao, Metta $\&$ Johnson, r 960 ) and chick ((USA) National Research Council, I 960 ) suggest that methionine and lysine are the limiting amino acids for these species. For the fowl lysine and methionine greatly increased the value of groundnut protein (Grau, I 946; Carpenter \& Ellinger, I95I), whereas addition of threonine as well had little effect (Grau, 1946). Added methionine and lysine have only a slight effect on utilization of groundnut protein by the rat (Balasundaram, Cama, Malik \& Venkateshan, I958; Bender, I96i). McOsker (I962) showed that threonine, as well as methionine and lysine, limits the value of groundnut protein for the rat.

These apparent differences between the chick and rat suggested the need for further investigation of groundnut-protein utilization. NPU $(\mathrm{op})$ tests (Miller \& Payne, I96I) have been carried out on diets containing groundnut flour (manufactured at Nigerian Oil Mills, Kano, and processed at less than $70^{\circ}$ ) to supply $\mathrm{I} \cdot 6 \%$ or $3 \cdot 2 \% \mathrm{~N}$. Addition of casein, a 'complete' amino acid mix, resembling casein in its essential amino acid content, or a similar mix with tryptophan omitted had similar effects in raising $\mathrm{NPU}_{(\mathrm{op})}$. Addition of amino acid mixes with lysine, threonine or methionine omitted, had but slight effect on NPU(op). Tests on diets containing $\mathrm{I} \cdot 6 \mathrm{~g} \mathrm{~N}$ from groundnut flour showed addition of DL-methionine, lysine hydrochloride or DLthreonine, either singly or in pairs, had little or no effect on NPU (op) but when all three were added, the $\mathrm{NPU}_{(\mathrm{op})}$ increased from 35 to $5 \mathrm{I}$, i.e. to approximately the value (52) noted after adding all the essential amino acids. Similar results were obtained in NPU tests on the commercial groundnut meal employed by Milner \& Carpenter 22 (2) 7 
(1963). These tests on groundnut flour and on groundnut meal, like those of McOsker ( 1962 ) on groundnut pastes, show that methionine, lysine and threonine are the three limiting amino acids, for the rat, in groundnut protein.

\section{REFERENCES}

Balasundaram, S., Cama, H. R., Malik, D. A. \& Venkateshan, C. (1958). I. Nutr. 66, 75.

Bender, A. E. (ז961). Publ. nat. Res. Coun., Wash., no. 843, p. 407.

Carpenter, K. J. \& Ellinger, G. M. (195 I). Biochem. F. 48, liii.

Grau, C. R. (1946). F. Nutr. 32, 303.

Harvey, D. (1956). Tech. Commun. Bur. Anim. Nutr., Aberd., no. 19.

McOsker, D. E. (1962). F. Nutr. 76, 453 .

Miller, D. S. \& Payne, P. R. (196I). F. Nutr. 74, 4I3.

Milner, C. K. \& Carpenter, K. J. (1963). Proc. Nutr. Soc. 22, xxii.

National Research Council. (1960). Publ. nat. Res. Coun., Wash., no. 827.

Rao, P. B. R., Metta, V. C. \& Johnson, B. C. (1960). F. Nutr. 7r, 327.

The limiting amino acids of groundnut flour and meal as the sole protein source for the chick. By C. K. Milner and K. J. Carpenter, School of Agriculture, University of Cambridge

Black \& Cuthbertson ( 1963 ) have reviewed the evidence for threonine being one of the three important limiting amino-acids in groundnut flour for rats. We have re-investigated the pattern of deficiency for chicks. Grau (1946) who fed a decorticated, extracted groundnut meal as the sole protein source for chicks, concluded that it was 'lacking primarily in methionine but also slightly deficient in lysine'.

We followed the general procedure of Grau (1946) but used a lower level of test material, contributing $14 \%$, instead of $20 \%$, crude protein, and eight groups of three chicks for each treatment. We also compared flour specially prepared for human consumption (Black \& Cuthbertson, 1963) with a commercial sample of decorticated extracted groundnut meal for animal feeding. The results for $\mathrm{g}$ gain/g food eaten over the io days of each experiment were:

\section{Amino acid supplement}

\section{None}

$0.32 \%$ DL-methionine (M)

$\mathrm{M}+0.36 \%$ L-lysine (L)

$\mathrm{M}, \mathrm{L}, 0.08 \%$ DL-tryptophan $(\mathrm{Tp})+0.4 \%$ glycine $(\mathrm{G})$

$\mathrm{M}, \mathrm{L}+0.24 \%$ L-threonine (Th)

$\mathrm{M}, \mathrm{L}, \mathrm{Th}, \mathrm{Tp}+\mathrm{G}$

$\mathrm{M}, \mathrm{L}, \mathrm{Th}+$ seven essential amino acids
M, L, Th+r.67\% L-glutamic acid

\begin{tabular}{|c|c|c|}
\hline \multirow{2}{*}{\multicolumn{2}{|c|}{ Groundnut flour }} & \multirow{2}{*}{$\begin{array}{l}\text { Commercia } \\
\text { meal } \\
\text { Expt } 2\end{array}$} \\
\hline & & \\
\hline 0.142 & 0.133 & 0.186 \\
\hline 0.297 & 0.295 & 0.317 \\
\hline $0.34 \mathrm{I}$ & 0.325 & 0.335 \\
\hline 0.325 & - & - \\
\hline 0.432 & $0.45 \mathrm{I}$ & 0.456 \\
\hline $0.44^{I}$ & - & - \\
\hline - & 0.462 & 0.483 \\
\hline 一 & 0.457 & $0.48 \mathrm{I}$ \\
\hline
\end{tabular}

With each material, while methionine and lysine gave a big improvement in growth, there was also a highly significant additional response to a further supplement with threonine.

With chicks as with rats, therefore, threonine has proved to be a limiting amino acid, though not to the same extent as methionine, for chicks. Our data are not really at variance with those of Grau (I946). He obtained values of 0.49 and 0.48 with supplements of $M$ and $L$ and $M, L$ and $T p$ respectively, and 0.57 and 0.52 with threonine added to these two combinations. He could use only small numbers with 
added threonine and this response was not statistically significant; it is, however, consistent with what we would expect, if on feeding more of our materials, the deficiency of the third limiting amino-acid became less severe.

From analytical data for groundnut meal (Ellinger \& Boyne, 1963) the methionine contributed by $20 \%$ groundnut protein should supply approximately $45 \%$, the lysine $72 \%$ and the threonine $83 \%$ of the chick's requirements (as estimated by the (USA) National Research Council (1960) for diets containing $20 \%$ protein). We cannot say whether or not our results with a lower protein level indicate that some of the threonine present is unavailable.

\section{REFERENCES}

Black, A. E. \& Cuthbertson, W. F. J. ( (963). Proc. Nutr. Soc. 22, xxi. Ellinger, G. M. \& Boyne, E. B. (1963). Proc. Nutr. Soc. 22, xxiii.

Grau, C. R. (1946). F. Nutr. 32, 303.

National Research Council. (1960). Publ. nat. Res. Coun., Wash., no, 827.

\section{Limiting amino acids in cereal : groundnut-meal diets for chicks. By} Gabrielle M. Ellinger and Elizabeth B. Boyne, Rowett Research Institute, Bucksburn, Aberdeen

In experiments with diets $\mathrm{I}-4$, containing different proportions of cereals and groundnut meal, procedure and basal diets were those described for the modified gross protein value (GPV) determination (Carpenter, Ellinger \& Shrimpton, 1955). Lysine and methionine singly and together were supplemented at the same levels as would be obtained from casein to give $3 \%$ protein. In diets 5 and 6 a semi-synthetic basal diet was used (Table I).

As the proportion of groundnut meal and total protein content of the diets increased, the limiting amino acid changed from lysine to methionine.

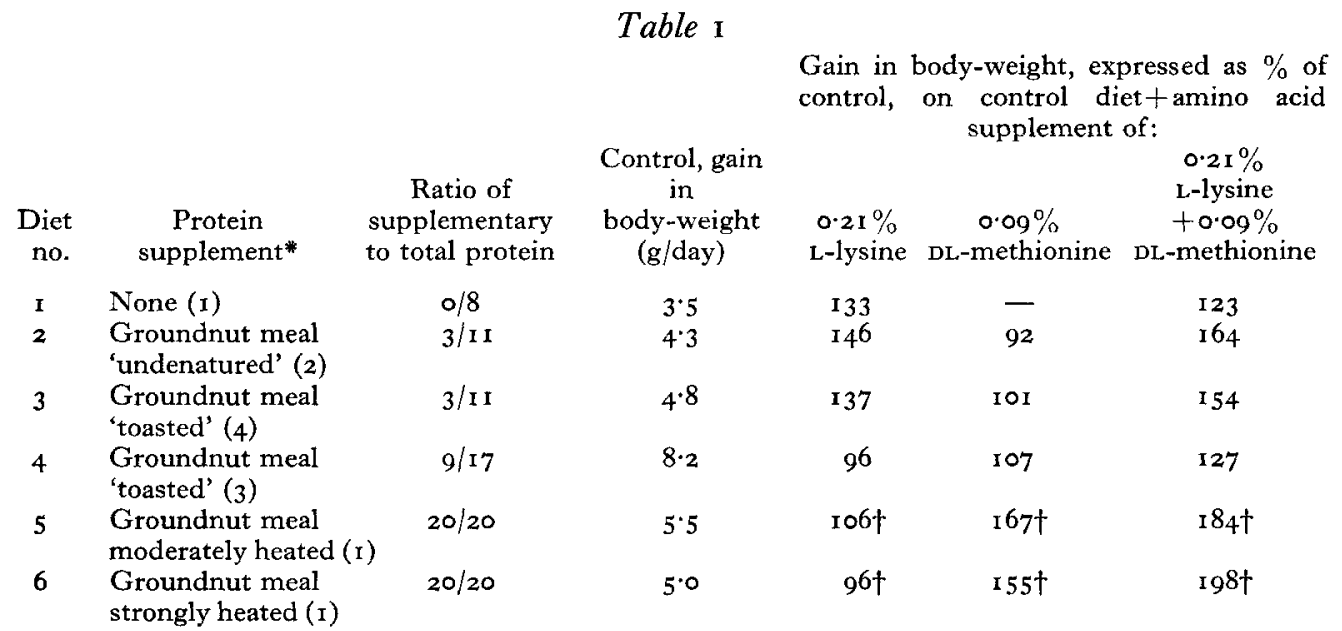

* Figures in parentheses are the numbers of trials.

†Amino acid supplementation at the rate of $0.3 \%$ of the diet. 
From amino acid analyses (Moore, Spackman \& Stein, I958) of a groundnut meal and of cereal basal diet, hydrolysed according to Dustin, Czajkowska, Moore \& Bigwood (1953), the composition of the experimental diets was calculated.

Table 2. Amino acid composition ( $g / 16 \mathrm{gN})$ of groundnut meal (1) and of GPV-type cereal basal (2)

\begin{tabular}{|c|c|c|c|c|c|}
\hline & (x) & (2) & & (I) & (2) \\
\hline Aspartic acid & $1.1 \cdot 4$ & $8 \cdot 2$ & Isoleucine & 3.5 & $4 \cdot 3$ \\
\hline Threonine & $2 \cdot 5^{*}$ & $4 \cdot 2^{*}$ & Leucine & $6 \cdot 5$ & $8 \cdot 1$ \\
\hline Serine & $5.0^{*}$ & $4 \cdot 8 *$ & Tyrosine & $4 \cdot 1$ & 3.5 \\
\hline Glutamic acid & $\mathrm{r} 8.8$ & $19 \cdot 6$ & Phenylalanine & $5 \cdot 4$ & $5 \cdot 0$ \\
\hline Proline & $4 \cdot 5$ & $7 \cdot 7$ & Lysine & $3 \cdot 6$ & 4.9 \\
\hline Glycine & $6 \cdot 1$ & $5 \cdot \mathrm{I}$ & Histidine & $2 \cdot 5$ & $2 \cdot 4$ \\
\hline Alanine & 4.0 & $6 \cdot 5$ & Arginine & I I 9 & $6 \cdot 1$ \\
\hline Valine & 4.5 & $5 \cdot 4$ & Cystine as cysteic acid & $\mathrm{I} \cdot 4$ & $2 \cdot 4$ \\
\hline Methionine & $1 \cdot 0$ & $1 \cdot 9$ & & & \\
\hline
\end{tabular}

Diet 4 , in its proportions of cereal and supplementary proteins, compared with rations used in practice. For this diet, according to analysis, the third limiting amino acid was estimated, by reference to the (USA) National Research Council's (I960) recommendations, to be amongst leucine, threonine, isoleucine and phenylalanine. However, no growth response was obtained with any one of these or with tryptophan.

\section{REFERENCES}

Carpenter, K. J., Ellinger, G. M. \& Shrimpton, D. H. (1955). F. Sci. Fd Agric. 6, 296.

Dustin, J. P., Czajkowska, C., Moore, S. \& Bigwood, E. J. (1953). Analyt. chim. acta, 9, 256.

Moore, S., Spackman, D. H. \& Stein, W. H. (1958). Analyt. Chem. 30, I185.

National Research Council. (1960). Publ. nat. Res. Coun., Wash., no. 827.

The digestibility of the carbohydrate constituents of artificially dried ryegrass, cocksfoot and timothy at various stages of growth. By R. WAITE, M. J. Johnston and D. G. Armstrong*, Hannah Dairy Research Institute, Kirkhill, Ayr

Three species of grass, ryegrass $\mathrm{S}_{24}$, cocksfoot $\mathrm{S}_{37}$ and timothy $\mathrm{S}_{4} 8$ were cut at the long leafy stage of growth and at $40 \%$ head emergence; a third cut of the cocksfoot and timothy was taken when all tillers had flowered. Approximately ${ }_{4} 4$ days separated successive cuts. The grasses were dried artificially and fed to sheep in calorimetric experiments designed to determine the net energy of the grasses (Armstrong, I $_{963}$ ). The analysis of the carbohydrate fractions of the grasses and their apparent digestibilities at a feeding level close to maintenance are given in the table.

Although cut at similar stages of growth, it is clear that the different growth habits of the three grasses had produced very different chemical compositions, the timothy showing most evidence of maturity. In all grasses the percentage of soluble carbohydrates decreased with advancing age of the grasses. There were corresponding

*Present address: King's College, University of Durham, Newcastle upon Tyne. 
Carbohydrate constituents of ryegrass $S_{24}$, cocksfoot $\mathrm{S}_{37}$ and timothy $\mathrm{S}_{4} 8$ at various stages of growth, together with their digestibility coefficients at a feeding level close to maintenance

\begin{tabular}{|c|c|c|c|c|c|c|c|c|}
\hline \multirow[b]{4}{*}{$\begin{array}{l}\text { Soluble carbohydrates } \\
\text { comprising }\end{array}$} & \multicolumn{2}{|c|}{ Ryegrass S24 } & \multicolumn{3}{|c|}{ Cocksfoot $\mathrm{S}_{37}$} & \multicolumn{3}{|c|}{ Timothy $\mathrm{S}_{4} 8$} \\
\hline & $\begin{array}{c}\text { Cut I, } \\
\text { late } \\
\text { leafy }\end{array}$ & $\begin{array}{c}\text { Cut 2, } \\
\text { flower } \\
\text { emergence }\end{array}$ & $\begin{array}{l}\text { Cut I, } \\
\text { late } \\
\text { leafy }\end{array}$ & $\begin{array}{c}\text { Cut 2, } \\
\text { flower } \\
\text { emergence }\end{array}$ & $\begin{array}{l}\text { Cut } 3 \text {, } \\
\text { flowering }\end{array}$ & $\begin{array}{l}\text { Cut I, } \\
\text { late } \\
\text { leafy }\end{array}$ & $\begin{array}{c}\text { Cut 2, } \\
\text { flower } \\
\text { emergence }\end{array}$ & $\begin{array}{c}\text { Cut 3, } \\
\text { flowering }\end{array}$ \\
\hline & \multicolumn{8}{|c|}{ Percentage of dry matter } \\
\hline & $18 \cdot 4$ & 13.5 & $12 \cdot 0$ & $5 \cdot 5$ & $5 \cdot 9$ & $7 \cdot 1$ & $5 \cdot 6$ & $5 \cdot 3$ \\
\hline Hexoses & $5 \cdot I$ & $5 \cdot 3$ & $3 \cdot 6$ & $3 \cdot 2$ & $3 \cdot 3$ & $2 \cdot 2$ & $2 \cdot 4$ & $2 \cdot 5$ \\
\hline Sucrose & $6 \cdot 8$ & $3 \cdot 8$ & $4 \cdot 8$ & $\mathrm{I} \cdot 4$ & $1 \cdot 9$ & $2 \cdot 2$ & $2 \cdot 3$ & $I \cdot 6$ \\
\hline Fructosan & $6 \cdot 5$ & $4 \cdot 4$ & $3 \cdot 6$ & 0.9 & 0.7 & $2 \cdot 5$ & 0.9 & $I \cdot 2$ \\
\hline Cellulose & $18 \cdot 5$ & $20 \cdot 9$ & $18 \cdot 0$ & $23 \cdot 8$ & $27 \cdot 2$ & $26 \cdot 2$ & $28 \cdot 4$ & $28 \cdot 9$ \\
\hline Hemicelluloses comprising & I $5 \cdot 1$ & 18.7 & $14 \cdot 6$ & $2 \mathrm{I} \cdot 1$ & $23 \cdot I$ & $24 * 4$ & $27 \cdot 2$ & 29.9 \\
\hline Xylan & $6 \cdot 9$ & $9 \cdot 5$ & $6 \cdot 4$ & $11 \cdot 3$ & 12.8 & $13 \cdot 8$ & 15.1 & $17 \cdot 2$ \\
\hline Araban & $I \cdot 5$ & $x \cdot 9$ & $1 \cdot 7$ & $2 \cdot 4$ & $2 \cdot 3$ & $2 \cdot 3$ & $2 \cdot 3$ & $2 \cdot 5$ \\
\hline Glucan & I. 9 & $\mathrm{I} \cdot 8$ & $I \cdot 8$ & $1 \cdot 7$ & $\mathrm{I} \cdot 8$ & $1 \cdot 3$ & $\mathrm{I} \cdot 7$ & $\mathrm{I} \cdot 6$ \\
\hline Galactan & 0.6 & 0.6 & 0.7 & 0.8 & 0.8 & 0.4 & 0.7 & 0.8 \\
\hline Aldobiouronics etc. & $4 \cdot 2$ & 4.9 & 4.0 & $4 \cdot 9$ & $5 \cdot 4$ & $6 \cdot 6$ & $7 \cdot 4$ & $7 \cdot 8$ \\
\hline \multirow[t]{2}{*}{ Pectin } & $2 \cdot 2$ & $2 \cdot 3$ & $2 \cdot 4$ & $2 \cdot 0$ & $2 \cdot 2$ & $1 \cdot 4$ & $\mathrm{I} \cdot 5$ & $I \cdot 6$ \\
\hline & \multicolumn{8}{|c|}{ Percentage digestibility } \\
\hline Soluble carbohydrates & 100 & 100 & 100 & 100 & 100 & 100 & 100 & 100 \\
\hline Cellulose & 94 & 86 & 89 & 85 & 79 & 82 & 75 & 65 \\
\hline Hemicelluloses & 87 & 79 & 85 & 79 & 71 & 79 & 72 & 63 \\
\hline Pectin & 71 & 59 & 54 & 42 & 44 & 29 & 27 & 25 \\
\hline
\end{tabular}

increases in the structural carbohydrates and these were contributed to more by increases in the hemicellulose fractions than by cellulose.

There was complete digestion of the soluble carbohydrates and the apparent digestibility of all the structural carbohydrates was highest in the youngest cuts. The fall in digestibility with maturity was greatest in the xylan-uronic acid fraction of all grasses and was high in the pectin of the ryegrass and cocksfoot. Cellulose (meaning here the pure glucan) was well digested in all cuts except the most mature timothy.

\section{REFERENCE}

Armstrong, D. G. ( $\left.1_{96}\right)$ ). Proc. Nutr. Soc. 22, xxv.

Net energy values for artificially dried ryegrass, cocksfoot and timothy.

By D. G. Armstrong*, Hannah Dairy Research Institute, Kirkhill, Ayr

The net energy values for fattening of eight artificially dried grasses were determined by feeding to sheep in respiration chambers. The grasses comprised three cuts each of cocksfoot $\mathrm{S}_{37}$, and timothy $\mathrm{S}_{4} 8$ and two cuts of ryegrass $\mathrm{S}_{24}$. Each cut was fed to each of four sheep at two levels; the lower level of feeding being close to, but above maintenance. The contents of gross energy and of metabolizable energy determined at the maintenance level are shown in the table together with the kcal net energy for fattening $\left(\mathrm{NK}_{\mathrm{F}}\right) / \mathrm{g}$ dry matter.

*Present address: King's College, University of Durham, Newcastle upon Tyne. 
Contents of gross energy, metabolizable energy and net energy for fattening $\left(N K_{F}\right)$ in eight samples of dried grass, expressed as kcal/g dry matter

\begin{tabular}{|c|c|c|c|c|c|}
\hline & & $\begin{array}{l}\text { Stage of } \\
\text { growth } \\
\text { when cut }\end{array}$ & $\begin{array}{l}\text { Gross } \\
\text { energy }\end{array}$ & $\begin{array}{c}\text { Metabolizable } \\
\text { energy }\end{array}$ & $\begin{array}{c}\text { Net } \\
\text { energy } \\
(\mathrm{NK} /)\end{array}$ \\
\hline Ryegrass S24 & $\begin{array}{l}\text { cut I } \\
\text { cut } 2\end{array}$ & $\begin{array}{l}\text { Young leafy } \\
\text { Late leafy }\end{array}$ & $\begin{array}{l}4.57 \\
4 \cdot 5^{8}\end{array}$ & $\begin{array}{l}3.23 \\
2.86\end{array}$ & $\begin{array}{l}\text { I } 67 \\
\text { I } \cdot 46\end{array}$ \\
\hline Cocksfoot $\mathrm{S}_{37}$ & $\begin{array}{l}\text { cut I } \\
\text { cut } 2\end{array}$ & $\begin{array}{l}\text { Young leafy } \\
\text { Late leafy }\end{array}$ & $\begin{array}{l}4 \cdot 78 \\
4 \cdot 63\end{array}$ & $\begin{array}{l}3.09 \\
2.78\end{array}$ & $\begin{array}{l}I \cdot 68 \\
\text { I. } 49\end{array}$ \\
\hline Timothy $\mathrm{S}_{4} 8$ & $\begin{array}{l}\text { cut } 3 \\
\text { cut I } \\
\text { cut } 2 \\
\text { cut } 3\end{array}$ & $\begin{array}{l}\text { Flowering } \\
\text { Late leafy } \\
\text { Flowering } \\
\text { Seed }\end{array}$ & $\begin{array}{l}4 \cdot 57 \\
4 \cdot 5^{8} \\
4 \cdot 54 \\
4 \cdot 51\end{array}$ & $\begin{array}{l}2.55 \\
2.71 \\
2.48 \\
2.08\end{array}$ & $\begin{array}{l}\text { I. I 5 } \\
\text { I.25 } \\
I \cdot 02 \\
0.87\end{array}$ \\
\hline
\end{tabular}

Within each species the content of metabolizable energy declined with increasing maturity. The major determinant of metabolizable energy content was the magnitude of the faecal energy loss which varied from $15.3 \%$ of the gross energy for the early cut of ryegrass to $43.0 \%$ for the very mature timothy. The net energy contents of the first cuts of cocksfoot and ryegrass were similar as were those for the second cuts of these two grasses. Values for ryegrass and cocksfoot were appreciably higher than for timothy.

The present findings provide further confirmation that the magnitude of the faecal energy loss is the major determinant of the value per unit of dry matter of dried forages as sources of energy for ruminant livestock.

The effect of the age of the pig and season of the year on the response to antibiotic and copper sulphate. By V. ANASTASIJEvic* and R. BRAUDE, National Institute for Research in Dairying, Shinfield, Reading, and J. G. RowELL, A.R.C. Statistics Group, School of Agriculture, University of Cambridge

The effects of oxytetracycline and copper sulphate added separately or together to rations of growing pigs were studied in a large-scale co-ordinated field experiment (Braude, Townsend, Harrington \& Rowell, I962). In this experiment which took 2 years to complete twenty-two centres located throughout the country co-operated and thirty-six replicates of four treatment groups with 245 pigs/treatment were involved. The overall results published previously could briefly be summarized that copper supplementation produced significantly larger improvement in growth rate and efficiency of food conversion than supplementation with oxytetracycline, and there was no advantage in supplementing the rations with both additives.

The data were further studied to determine whether the observed effects were similar in the first and second half of the growing period (up to $\mathrm{I} 20 \mathrm{lb}$ live weight, and from $\mathrm{I} 20 \mathrm{lb}$ to slaughter at about $200 \mathrm{lb}$ ) and during the winter and summer seasons (arbitrarily divided into two periods: experiments starting I April-3o September, and I October-3 I March).

*British Council Scholar from Institute for Livestock Breeding, Zemun Polje, Yugoslavia. 


\section{Mean growth rate and efficiency of food conversion}

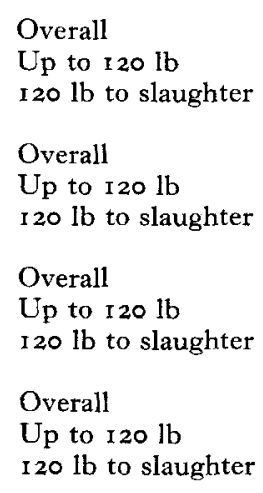

\begin{tabular}{|c|c|c|}
\hline \multicolumn{3}{|c|}{ Growth rate (lb/day) } \\
\hline Throughout & & \\
\hline the year & Summer & Winter \\
\hline \multicolumn{3}{|c|}{ Control } \\
\hline $1 \cdot 34$ & I 35 & $I \cdot 33$ \\
\hline $1 \cdot 17$ & $1 \cdot 17$ & $I \cdot 17$ \\
\hline$I \cdot 5^{2}$ & $x \cdot 55$ & $I \cdot 50$ \\
\hline \multicolumn{3}{|c|}{ Oxytetracycline } \\
\hline$I \cdot 38$ & $I \cdot 40$ & $I \cdot 36$ \\
\hline $1 \cdot 22$ & $I \cdot 24$ & $I \cdot 20$ \\
\hline $1 \cdot 56$ & $I \cdot 59$ & $I \cdot 53$ \\
\hline \multicolumn{3}{|c|}{ Copper sulphate } \\
\hline$I \cdot 47$ & $I \cdot 47$ & $I \cdot 46$ \\
\hline$I \cdot 3 I$ & $I \cdot 30$ & $I \cdot 32$ \\
\hline $1 \cdot 63$ & $1 \cdot 66$ & $I \cdot 6 I$ \\
\hline \multicolumn{3}{|c|}{ Copper sulphate + oxytetracycline } \\
\hline$I \cdot 46$ & $I \cdot 47$ & $I \cdot 46$ \\
\hline$I \cdot 3^{2}$ & $I \cdot 3 I$ & $1 \cdot 33$ \\
\hline$I \cdot 62$ & $I \cdot 65$ & $I \cdot 60$ \\
\hline
\end{tabular}

\begin{tabular}{|c|c|c|}
\hline \multicolumn{3}{|c|}{$\begin{array}{l}\text { Efficiency of food conversion (lb } \\
\text { feed/lb live-weight gain) }\end{array}$} \\
\hline $\begin{array}{l}\text { Throughout } \\
\text { the year }\end{array}$ & Summer & Winter \\
\hline \multicolumn{3}{|c|}{ Control } \\
\hline $3 \cdot 56$ & $3 \cdot 5 \circ$ & $3 \cdot 60$ \\
\hline $3 \cdot 10$ & 3.08 & $3 \cdot 12$ \\
\hline $3 \cdot 95$ & Oxytetracycline & $4 \cdot 04$ \\
\hline $3 \cdot 48$ & $3 \cdot 39$ & $3 \cdot 54$ \\
\hline $3 \cdot 02$ & $2 \cdot 95$ & $3 \cdot 08$ \\
\hline \multicolumn{3}{|c|}{ Copper sulphate } \\
\hline $\begin{array}{l}3 \cdot 27 \\
2 \cdot 82\end{array}$ & $\begin{array}{l}3.21 \\
2.80\end{array}$ & $\begin{array}{l}3 \cdot 32 \\
2 \cdot 84\end{array}$ \\
\hline $3 \cdot 68$ & $3 \cdot 59$ & $3 \cdot 75$ \\
\hline \multicolumn{3}{|c|}{ Copper sulphate + oxytetracycline } \\
\hline $\begin{array}{l}3 \cdot 30 \\
2 \cdot 82\end{array}$ & $\begin{array}{l}3 \cdot 27 \\
2 \cdot 84\end{array}$ & $\begin{array}{l}3 \cdot 33 \\
2 \cdot 81\end{array}$ \\
\hline $3 \cdot 71$ & $3 \cdot 62$ & $3 \cdot 78$ \\
\hline
\end{tabular}

Mean growth rate and efficiency of food utilization are summarized in the table. The results of the summer and winter replicates combined show that the percentage improvement due to addition of oxytetracycline or copper sulphate was larger in the period up to $\mathrm{I} 2 \mathrm{O} \mathrm{lb}$ live weight than thereafter. For each supplement the response was significant in each half of the experimental period, significantly better with copper sulphate than with oxytetracycline, with no significant improvement resulting from adding both supplements. The response to oxytetracycline or copper sulphate did not differ significantly between summer and winter (both comparisons being made with the control groups).

\section{REFERENCE}

Braude, R., Townsend, M. J., Harrington, G. \& Rowell, J. G. (1962). F. agric. Sci. 58, 25 I.

Vitamin $B_{12}$ and its analogues in the gut contents of germ-free and conventional chicks. By M. E. Contes, M. E. Gregory, J. W. G. Porter and A. P. Williams, National Institute for Research in Dairying, Shinfield, Reading It is generally assumed from indirect evidence that the vitamin $B_{12}$-like factors present in faeces and intestinal contents are products of bacterial synthesis. To obtain direct evidence on this point, caecal contents and droppings from germ-free chicks have been examined for vitamin $\mathrm{B}_{12}$ activity.

Germ-free chicks were reared in the Gustafsson apparatus as described by Coates, Fuller, Harrison, Lev \& Suffolk (1963). They were given a sterilized purified diet in which crystalline cyanocobalamin was the only source of vitamin $\mathrm{B}_{12}$; hatch-mates were reared on the same diet in a conventional environment. In the first experiment the birds were killed at 4 weeks of age and the pooled caecal contents of sixteen germfree or conventional chicks, and the diet, were assayed microbiologically for vitamin 
$\mathrm{B}_{12}$ with three different micro-organisms. In a second experiment, droppings (inevitably containing some scattered diet) from germ-free and conventional chicks were extracted with aqueous acetone. The aqueous layer was extracted with phenol which was subsequently removed with ether, and the extracts were assayed with Escherichia coli and Ochromonas malhamensis. The methods of assay were those of Ford (1953), and the results were:

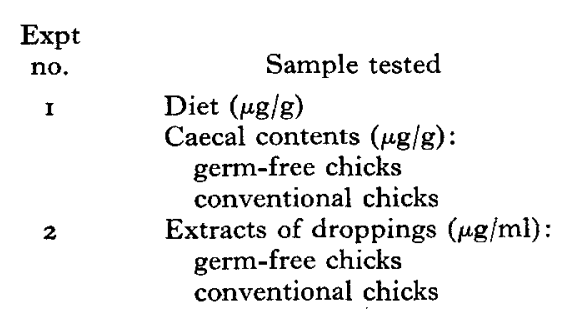

$\begin{array}{lll}\begin{array}{c}\text { L. leichmannii } \\ 0.0073\end{array} & \begin{array}{c}\text { O. malhamensis } \\ 0.007 \mathrm{I}\end{array} \\ 0.0069 & \text { Assay organism } & 0.0010 \\ 0.0014 & 0.0008 & 0.10 \\ 0.46 & 0.55 & 0.049 \\ 0.064 & - & 0.205 \\ 1.07 & - & 0\end{array}$

As expected, caecal contents and droppings of conventional birds had much greater vitamin $B_{12}$ activity than those of germ-free birds. The higher values found with E. coli or Lactobacillus leichmannii as compared with those with $O$. malhamensis indicate that much of the activity was contributed by factors other than true vitamin $B_{12}$. However, for the germ-free birds values were similar with the different organisms hence the small amount of activity detected was probably entirely due to true vitamin $\mathrm{B}_{12}$.

Examination by chromatography and ionophoresis showed the presence of vitamin $B_{12}$, factors $A, B$, pseudovitamin $B_{12}$ and probably factor $F$ in the droppings of conventional chicks, but only vitamin $B_{12}$ in those of germ-free birds. It is concluded that there is no synthesis of vitamin $\mathrm{B}_{12}$-like factors in germ-free conditions; the very low levels of true vitamin $B_{12}$ in the samples from germ-free chicks suggest that its synthesis is also unlikely in the absence of a gut flora.

We are grateful to our colleague, Dr. R. Fuller, for sterility checks of the germ-free birds.

\section{REFERENCES}

Coates, M. E., Fuller, R., Harrison, G. F., Lev, M. \& Suffolk, S. F. (1963). Brit. f. Nutr. 17, I41. Ford, J. E. (1953). Brit. F. Nutr. 7, 299.

An inquiry into nutritional status in the Aden Protectorate. By B. T. SQuiREs, Human Nutrition Research Unit, National Institute for Medical Research, Mill Hill, London, N.W.7

The Aden Protectorate, which stretches along the South Arabian coast from the Red Sea to the Oman border, has an estimated area of $c$. I I 2000 sq. miles and carries a population of $c .700000$. There are very few large settlements, the largest having a population of $\mathrm{i} 8000$.

The country consists mainly of mountains, valleys and deserts and only $1-2 \%$ of the total area is cultivable. The total rainfall, which is essentially erratic, varies within the range o-I 2 in./annum and falls chiefly in the mountain and foothill areas. 
On the coastal strip, where rain very rarely falls, no crops can be grown without irrigation. Communications are primitive; there are no railways, roads are poor and transport is dependent almost entirely on camels and lorries.

Agriculture, but little above maintenance level, is the chief source of employment. Other sources, such as fishing, building and service in the various armed forces, are small.

Cereals, chiefly sorghum and millet, form the staple food. Meat (mutton and goat) is eaten only once a week or so or on feast days, by most people and is not a major article of diet. Fish is consumed in the coast areas and some dried fish is exported to inland centres, but difficulties of transport, storage and distribution have so far prevented the development of a large fishing industry. Many varieties of fruit and vegetables can be grown but the Protectorate Arabs consume only dates, radishes (raw) and tomatoes (always cooked) in any quantity. Milk and milk products are very scarce and dear and fat for cooking is obtained almost entirely from sesame oil.

Protein-calorie deficiency is rife and becomes more obvious in the areas remote from the coast. No vital statistics are obtainable but it is estimated from a series of family histories involving nearly 700 children that the infant mortality was $188 / 1000$, and the child mortality in the age group $\mathrm{I}-4$ years was $92 / 1000$. Compared with some other countries, the situation, although poor, does not appear desperate. Development of the fishing industry, improvement of agricultural methods, cold storage facilities, and communication and advancement of education, should change the picture within a generation.

Transverse trabeculae in the bones of malnourished children. By $H$. S. PlatT, University College Hospital, Ibadan, Nigeria, and R. J. C. Stewart and B. S. PlatT, Human Nutrition Research Unit, Nutrition Building, National Institute for Medical Research, Mill Hill, London, N.W.7

Transverse striations, arrested growth lines and lattice formations have been observed in radiographs of the bones of children suffering from infections, metabolic disturbances and vitamin deficiencies as well as general malnutrition. Histologically the bones show a reduction in the rates of cartilaginous growth and maturation, reduced osteoblastosis with less severe effects on osteoclasis. Such findings have encouraged the suggestion that bone reacts in a non-specific manner to caloric restriction, deficiencies of single nutrients or other stress.

We have obtained bones from Nigerian children of different ages who died after periods of infection and malnutrition. All the changes, radiological and histological, are of a similar type varying only in degree. It might therefore be assumed that conditions as diverse as tuberculosis, endomyocardial fibrosis, poliomyelitis, lymphatic leukaemia and otitis media produced similar non-specific reactions in bone. Recently, however, Platt \& Stewart (I962) suggested that the transverse trabeculae, striations and arrested growth lines were a direct effect of protein-calorie deficiency which could be brought about by low intakes of food especially during infectious episodes when the appetite may be impaired and the needs of the body are high. Changes 
similar to those observed in the children's bones have been seen in the bones of pigs and dogs which, although maintained on diets of low protein value, did not suffer from any infection. Weight in relation to age is a good indicator of the nutritional status of children, twenty-four of the twenty-seven children whose bones have been examined were underweight for age, so that protein-calorie deficiency would appear to be a common factor. It should be appreciated that the assessment of age is at times only approximate since births until recently were not registered.

Specific changes in the structure of the bones of animals can be brought about by deficiencies of vitamins A, C or D, calcium and other minerals, as well as by protein, but as loss of appetite and consequently a reduced food intake usually accompanies these deficiencies the bones often show a so-called non-specific change which is indicative of the attendant protein-calorie deficiency. The changes seen in the children's bones are therefore probably due to a protein-calorie deficiency which may have been intensified or even initiated by the infections and other disturbances.

We are grateful to Professor G. M. Edington of the Department of Morbid Anatomy for permission to use the post-mortem material which was obtained from patients who died at University College Hospital, Ibadan, Nigeria.

\section{REFERENCE}

Platt, B. S. \& Stewart, R. J. C. (1962). Brit. F. Nutr. 16, 483 .

The interaction of protein and calcium on the growth and composition of bones in young rats. By N. R. H. El-Maraghi and R. J. C. STEWART, Human Nutrition Research Unit, Nutrition Building, National Institute for Medical Research, Mill Hill, London, N.W.7

In an attempt to evaluate the relative importance of protein and calcium in the development of osteoporosis, male weanling rats were maintained for 56 days on diets having protein values of $\mathrm{NDpCal} \%=\mathrm{I} 0 \cdot 2,6 \cdot 0,5^{\cdot} \mathrm{I}$ and $4 \cdot 5$. Three diets of each protein value were used, containing respectively $0.44,0.22$ and $0.11 \%$ of $\mathrm{Ca}$. The animals received complete vitamin mixtures and only distilled water to drink. As rats maintained on diets of low protein value consume less food than normally growing animals, some were given the high-protein diet $(\mathrm{NDpCal} \%=\mathrm{IO} \cdot 2)$ in amounts equal to those eaten by the animals maintained on the low-protein $\operatorname{diet}(\mathrm{NDpCal} \%=4.5)$. The animals given the diets with the higher protein values grew faster than did those on the low-protein diets (measured by body-weight and bone length).

The radiographic density of the bones, when the diet contained $0.44 \% \mathrm{Ca}$, was greatest in the animals receiving the diets of high protein value; conversely, with the low intakes of $\mathrm{Ca}(0 . \mathrm{I} \%)$ it was greatest in the bones of the animals receiving the diets of low protein value.

The ash content of the bones, expressed as $\mathrm{mg} / \mathrm{cm}^{3}$ to minimize differences due to bone size, confirms the radiographic appearances (see table). When the intake of food by two groups was equal but the protein values of the diets were different, the 
animals given a diet of high protein value containing $0.44 \% \mathrm{Ca}$ showed an increased growth, radiographic density and ash content of the bones ( $a$ and $b$ ), whereas when the $\mathrm{Ca}$ intakes were low, those given a diet with a high protein value had large bones with a lower radiographic density and ash content ( $c$ and $d)$.

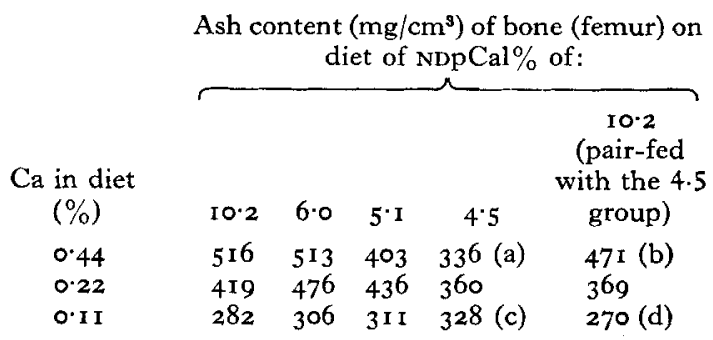

An osteoporosis-like condition may therefore be produced in growing animals when protein and $\mathrm{Ca}$ intakes are unbalanced and, in the treatment of bone rarefaction, attention should be directed to the relative proportions of protein and $\mathrm{Ca}$ as well as to the total amounts in the diet.

\section{Nutritional knowledge and food preferences of students of teacher training colleges. By J. C. McKenzie and John Yudkin, Department of Nutrition, Queen Elizabeth College, University of London}

This paper gives an interim report of a study, designed to last at least 3 years, which is being conducted at two London training colleges for women, one specializing in domestic science (D) and one giving a normal teacher training course (T). Our intention is, first, to assess the ways in which food habits and preferences change with increased knowledge and experience of food and nutrition in domestic science students, and second, to compare the students who have this somewhat special interest with students who do not have it.

All students of ' $T$ ' and the rst-year students of $D$ were asked to select from a list of foods those which were rich sources of protein, iron, carbohydrate, calcium or vitamin C. Over $90 \%$ in each group could correctly identify foods containing a good deal of carbohydrate or calcium, but the results for the other nutrients were less satisfactory. For example, only $48 \%$ of $\mathrm{T}$ students gave two correct answers for protein. In every case $\mathrm{D}$ students gave better answers than $\mathrm{T}$ students. However, when asked to assess the truth or falsehood of a set of sayings, D students, although still better than $\mathrm{T}$, showed a considerable inability to apply their nutritional knowledge. Over half the students of $D$ thought that canned foods are less nutritious than fresh foods, and that lemon juice is good for slimming. In both groups of students, nearly $40 \%$ did not know any of the organizations concerned with world food problems.

Students from the 1 st, 2nd and 3 rd year at both colleges were given a list of foods and asked to signify whether they liked or disliked them, were indifferent to them, or had never tried them. In $D$, the number of foods never tried decreased from an average of $5 \%$ in the Ist year to $2 \%$ in the 3 rd year. There was no clear pattern for $T$ 
students, although at every stage the percentage of foods not tried or disliked was above that for the D students. Similar food preferences were found in both colleges: chipped and roast potatoes, grilled steak, chicken, apples, peaches, grapes and strawberries were almost universally liked.

Any conclusions must at this stage be tentative but there is no indication that food preferences are favourably modified by the domestic science students in the light of widening food experience and nutritional knowledge. The dislike of foods is spread equally amongst those which may be regarded nutritionally as good foods or as bad foods. Specialist (domestic science) students have at the beginning of the course a good idea of the nutrient content of various foods but do not reliably apply this to their choice of food. Non-specialist students have only a fair knowledge of nutrition and it does not appear to change during the 3 years they are at college.

The effect of a non-ionic surface-active agent on the digestibility of triglycerides and free fatty acids in the pig. By H. S. BAYLEY and D. LEwIS, University of Nottingham School of Agriculture, Sutton Bonington, Loughborough

Bolton (I96I) found that the digestibility of beef tallow in the chick was increased by the addition of a non-ionic surface-active agent to the ration. This suggests that emulsification of the fat normally limits the digestibility of tallow in the chick. This experiment investigated the effect of adding $0.1 \%$ of Lissapol $\mathrm{N}$ (nonylphenol ethylene oxide condensate) to rations containing either $10 \%$ of beef tallow or $10 \%$ of free fatty acids derived from the beef tallow by catalytic hydrolysis. The rations used are described by Bayley \& Lewis (1963).

Each ration was fed to four pigs of about $60 \mathrm{~kg}$ live weight which were housed in cages permitting the collection of urine and faeces. A ro-day preliminary period was followed by a I2-day collection period. The total fat content and the fatty acid composition of the food and faeces were determined as described by Bayley \& Lewis (1962). The faecal fat output determined by feeding four pigs the extracted basal ration was used to calculate the corrected digestibilities.

The results in Table $\mathrm{I}$ show that the free fatty acids were less well digested than the triglycerides. This was particularly true of palmitic and stearic acids whereas oleic

Table I. Corrected digestibilities of fat and fatty acids in the pig

\begin{tabular}{|c|c|c|c|c|c|c|}
\hline & \multirow{2}{*}{$\begin{array}{l}\text { Total } \\
\text { lipid }\end{array}$} & \multicolumn{5}{|c|}{ Fatty acid } \\
\hline & & Myristic & Palmitic & Linoleic & Oleic & Stearic \\
\hline Tallow triglycerides & $7 \mathrm{I}$ & 86 & 62 & 96 & 87 & 23 \\
\hline Tallow free fatty acids & 54 & 54 & 28 & 94 & 83 & $-v e$ \\
\hline 'Tallow triglycerides + surfactant & $7 x$ & 82 & 60 & 98 & 86 & $3 \mathbf{I}$ \\
\hline Tallow free fatty acids + surfactant & 60 & 74 & 42 & 99 & 86 & I I \\
\hline Least significant difference, $\mathrm{P}=0.05$ & $7 \cdot 2$ & $5 \cdot 8$ & $9 \cdot 2$ & $6 \cdot 5$ & $3 \cdot 4$ & $17 \cdot 8$ \\
\hline
\end{tabular}

The fat was added as $10 \%$ of the complete ration and the surfactant, lissapol N (I.C.I. Ltd) constituted $0.1 \%$ of the ration. The 'endogenous' faecal fat output was $1 \mathrm{I} \cdot 4 \mathrm{~g} /$ day and consisted of: $14: 0,0.15 \mathrm{~g}$; I $5: 0,0.70 \mathrm{~g} ; 16: \mathrm{I}, 0.1 \mathrm{Ig} ; \mathrm{I} 6: 0,2.50 \mathrm{~g} ; \mathrm{I} 7: 0,0.48 \mathrm{~g} ; \mathrm{I} 8: 2,0.58 \mathrm{~g} ; \mathrm{I} 8: 1,0.98 \mathrm{~g}$ and I $8: 0,4.56 \mathrm{~g}$ plus $\mathrm{I} \cdot 34 \mathrm{~g}$ of ether-soluble non-saponifiable material. 
and linoleic acids were well digested when fed either as the free acid or as the triglyceride. The addition of the detergent resulted in an improvement in the overall digestibility of the free acids, but had no effect on the utilization of the triglycerides.

The results suggest that incomplete emulsification of the free fatty acids may be the cause of their lower digestibility, since the addition of surface-active agent results in an increased absorption.

\section{REFERENCES}

Bayley, H. S. \& Lewis, D. (1962). Proc. Nutr. Soc. 21, xxv. Bayley, H. S. \& Lewis, D. (r963). F. agric. Sci. (In the Press.) Bolton, W. ( (961). F. agric. Sci. 57, 83 .

The effect of feeding individual amino acids on adrenocortical activity. By H. N. Munro, Marian H. Steele and W. C. Hutchison, Department of Biochemistry, University of Glasgow

When glycine, methionine or leucine is fed to rats in single large doses, there is an increased incorporation of ${ }^{32} \mathrm{P}$ into liver ribonucleic acid and a deposition of glycogen in the liver (Munro \& Mukerji, 1958, 1962). Since these effects are also observed after administration of cortisone, and since the feeding of methionine or leucine to adrenalectomized rats fails to produce changes in liver ribonucleic acid metabolism, it was concluded that the giving of single amino acids influences the function of the adrenal cortex (Munro \& Mukerji, 1962). The present communication reports the effects of prolonged feeding of these amino acids on adrenocortical size and composition, and on secretion of adrenocortical hormones.

Diets were fed to rats for II days in which the nitrogen source was either casein, zein supplemented with tryptophan and lysine, unsupplemented zein, gelatin or the single amino acids glycine, methionine or leucine. As compared with animals receiving a protein-free diet, casein and zein with tryptophan and lysine caused a significant increase in adrenal size and in its content of protein and ribonucleic acid. No significant change in adrenal size or constituents was observed when the diet contained zein alone, gelatin or the individual amino acids as the sole source of dietary nitrogen. This implies that adrenal size and gross composition are sensitive only to diets providing nutritionally complete proteins.

The plasma and adrenal concentrations of corticosterone were also measured after administering these forms of dietary nitrogen. At $24 \mathrm{~h}$ after feeding methionine or leucine, there was a significant elevation of plasma corticosterone level. After I I days of feeding, the total corticosterone content of the adrenal gland was significantly raised by giving glycine, methionine or leucine, and also by giving casein or zein supplemented with tryptophan and lysine. No elevation was caused by unsupplemented zein or by gelatin.

It would thus appear that the dietary factors causing increased formation and secretion of corticosterone by the rat adrenal gland are independent of those responsible for changes in gland size and composition. 
Total amount of iron in the pregnant mouse and her offspring. By P. V. J. Hegarty and G. R. Wadsworth, Department of Nutrition, Sir fohn Atkin's Laboratories, Queen Elizabeth College, University of London

In foetal life and, usually, during infancy iron is obtained solely from the mother. Very few studies have been made of the relationship between maternal $\mathrm{Fe}$ and that of the young by experiments involving simultaneously various stages of pregnancy and postpartum life. But this aspect of Fe metabolism is of obvious importance.

The initial results of an experiment in which total carcass Fe is being measured in mice are reported in this communication. The animals are fed diet $4^{\mathrm{I}} \mathrm{B}$ (Rank) in which the $\mathrm{Fe}$ content is about $10 \mathrm{mg} / \mathrm{roO} \mathrm{g}$. After mating batches of animals are killed at intervals. The Fe in the entire carcass, including the blood, is estimated by Wootton's (1958) method. The results are given in Tables I and 2.

Table I. Mean quantities of iron in the bodies of mice during pregnancy

$\begin{array}{crc}\begin{array}{c}\text { Duration of } \\ \text { pregnancy } \\ \text { (days) }\end{array} & \text { No. } & \begin{array}{c}\text { Total Fe } \\ (\mu \mathrm{g})\end{array} \\ 7 & 12 & 226 \\ 9 & 5 & 236 \\ \text { 1 I } & 6 & 269 \\ 16 & 4 & 249 \\ \text { 19 } & 5 & 292\end{array}$

Table 2. Mean quantities of iron in the bodies of female mice and their offspring

$\begin{array}{ccccc}\begin{array}{c}\text { Days } \\ \text { after }\end{array} & \begin{array}{c}\text { No. of } \\ \text { families }\end{array} & \text { Mothers } & \text { Total Fe }(\mu \mathrm{g}) & \begin{array}{c}\text { Mothers } \\ + \\ \text { delivery }\end{array} \\ \text { I } & 2 & 216 & 97 & \text { pups } \\ 7 & 2 & 259 & 125 & 313 \\ \text { I4 } & 13 & 336 & 229 & 383 \\ \text { 21 } & 2 & 383 & 585 & 965\end{array}$

There is a progressive increase in the quantity of Fe during pregnancy. This could be due mainly to that accumulating in the foetuses as indicated by the amount in the young soon after birth. After delivery the mothers continue to gain $\mathrm{Fe}$, as do the young to a much greater extent. The combined amount of $\mathrm{Fe}$ in mothers and young is very much more than that in mice at an early stage of pregnancy.

The young mice have access to food in the cages, but it is probable that they obtain much of their Fe from the mother's milk. The mother may get the extra Fe by increasing the amount of food eaten, increasing the proportion of dietary Fe absorbed, or by both means.

\section{REFERENCE}

Wootton, I. D. P. (1958). Biochem. F. 68, 197. 